\title{
THE SPECIES OF TEREDO FROM PLYMOUTH WATERS
}

\author{
By Marie V. Lebour, D.Sc. \\ Naturalist at the Plymouth Laboratory
}

(Text-figs. I-3)

In the many references to Teredo from Plymouth early workers assumed that the common form was $T$. navalis L. Orton (1913) refers to this species, but he has recently told me that he did not try to identify the species precisely. It is almost certain that he was dealing with $T$. norvegica Spengler, which, it is now known, is the common large species in these waters. Harington (1922) ascribes the species with which he worked at Plymouth to $T$. norvegica, with a query, and no doubt he identified the species correctly. Yonge (I926) states that the Teredo with which he worked from the experimental raft near Plymouth Breakwater were probably all $T$. norvegica. Later he identified them as that species. Unlike T. navalis it does not carry its young in a brood pouch, but sends its eggs directly into the sea.

Three species have been found in recent years from the Plymouth district, two from the experimental raft moored near the Breakwater and from other fixed wood, and one from driftwood. The two commonly occurring from the raft are (I) T. norvegica and (2) a much smaller species carrying its young in a brood pouch, closely related to, if not identical with, $T$. navalis. The third species, occurring occasionally in driftwood, is T. megotara Forbes \& Hanley. Purchon (I94I), who worked at the last species from specimens in a tank at the Plymouth Laboratory, saw no sign of a brood pouch; and in those collected later from Wembury and examined by myself it was found that the eggs, shed directly into the sea, were very numerous. It is then practically certain that the young are not carried by the parent.

Kofoid (1922) has identified specimens of a Teredo from Plymouth as $T$. navalis, but the small form noted above, although coming very close to that species, and possibly merely a variety, differs in many ways from the American species as described by him (I922) and recognized by Grave (I928). $T$. navalis, $T$. norvegica and $T$. megotara are the three common species usually recorded from British waters, and these are figured by Calman \& Crawford (1936). Xylophaga dorsalis (Turton), a wood-boring mollusc recently studied by Purchon (I94I) and placed by him in a separate family, although usually found in driftwood, was also found in the raft with Teredo. Nothing is so far known of its breeding, although Purchon regards it as possible, from the anatomy, that it possesses a brood pouch, and he shows that self-fertilization is possible. From the notes given below it seems, however, that it is unlikely that it carries its young. 
T. navalis and $T$. norvegica are both recorded in the Plymouth Marine Fauna (I93I), but the records of the former are based on notes made before the two species were discriminated and are unreliable. Mr R. Winckworth has kindly examined the small species for me and is of the opinion that it is $T$. navalis. Mr G. I. Crawford; of the British Museum, has also examined it and tells me that it seems to be the species normally regarded as $T$. navalis. It is therefore here placed in that species, as a variety, although it differs to a considerable extent in several particulars from available descriptions.

With the object of ascertaining the breeding seasons of the Plymouth species of Teredo, specimens from the raft were examined every month for over a year, and afterwards from time to time. Both species were almost constantly present and were breeding throughout the year. Although the breeding was heavier in both species in spring and summer, ripe ova were present in T. norvegica and active veligers in $T$. navalis (small form) in any month-a fact of interest since the breeding season of most or all the American species is much restricted.

It is the small species, here called $T$. navalis var., which has proved to be specially interesting. Compared with the American descriptions of T. navalis it differs in many ways. Apart from the old records from Plymouth, which, as is shown above, do not discriminate the species, and the fact that Kofoid (1922) has identified a species sent to him from Plymouth as T. navalis, this small species has not been specially noted here. Unfortunately there are no specimens available in the Plymouth collections, nor from any previous worker, except $T$. norvegica. It is probable, however, that this $T$. navalis var. has been present with $T$. norvegica for some time.

$T$. navalis var. differs considerably from $T$. navalis as described by the older workers. Forbes \& Hanley (I853) and Jeffreys (1865) give long descriptions which may easily cover many forms; but by both it is described as capable of attaining a large size, and it may reach to over a foot in length, although it may breed at 4 in., whereas the present small form rarely exceeds 2 in. and is usually smaller, breeding at well below an inch. The figures of the pallets given by both authors agree with those of the American $T$. navalis and not with those of the small form from Plymouth. They also differ in certain points of their anatomy.

The form of the pallet is usually regarded as an important character, and in T. navalis it is always described as having a forked tip. Bartsch (I922) has, however, recognized several species with forked tips and separates $T$. navalis and its near relatives from certain other closely allied forms by the fact that the pallets end in a cup-shaped depression. The pallet is composed of a calcareous stalk and blade which is covered at its distal end with a dark periostracum. In $T$. navalis proper the calcareous portion ends in a cup-shaped depression, the contours being followed by the dark periostracum. In $T$. townsendi Bartsch and $T$. diegensis Bartsch the calcareous portion is rounded distally instead of being cup-shaped. In $T$. townsendi the periostracum rises up to form 
a fork. In $T$. diegensis it projects a long way beyond the rounded calcareous end and bears a calcareous nodule distally, the distal margin being straight and not forked. In the small Plymouth form the pallets, unlike $T$. navalis proper, are rounded and not cup-shaped at the end of the calcareous portion, the dark periostracum projecting far beyond as in $T$. diegensis, but the ends may be either forked or straight, or may have an intermediate form. Usually there is no calcareous nodule, but in many cases there is a calcareous deposit at the end of the periostracal portion, thus approaching $T$. diegensis. It seems likely that the calcium is present to a greater extent in older specimens. Bartsch (I922) finds differences also in the shells of these species, but Miller (I922) has shown that the shells of Teredo vary enormously. As Bartsch's monograph deals with the hard parts only it is difficult to be sure that all his species are valid. It seems that $T$. townsendi and $T$. diegensis are very much alike, and the Plymouth $T$. navalis var. closely resembles the-latter. All three are very small and stand apart in the matter of pallets from the typical $T$. navalis. Kofoid (I92I) notes certain differences in his $T$. navalis and $T$. diegensis (the latter being the $T$. townsendi of Bartsch and not his $T$. diegensis), and his descriptions, together with those of Bartsch, seem to indicate two quite distinct forms, if not species. The three types of pallet are regarded by Bartsch as even of subgeneric value.

T. navalis proper and the small form from Plymouth, $T$. navalis var., have in common the following characters: the embryos are carried in a brood pouch; the pallets are forked or tend to be forked, are paddle-shaped and covered distally with a brown periostracum; the tube has a smooth calcareous lining without ridges or chambered partitions near the opening; the shell is very like that of $T$. norvegica but is smaller, and there are slight differences in the proportions of parts; the young are held in the brood pouch until they are strongly developed veligers which are released through the exhalant siphon; the anterior portion of the ctenidium is composed of five filaments, as describedby Lazier (I924), who investigated the anatomy of $T$. navalis from America.

The following characters distinguish the two forms:

Teredo navalis L. (according to Kofoid) from America. The pallets have a cup-like indentation at the distal end, formed of both calcareous and periostracal portions; the siphons are very unequal and are coloured and spotted by a red pigment; the body is long and thin; the breeding season is between May and October, and no breeding females occur later than the middle of October nor earlier than May; the veligers, according to Grave, may swim about in the open sea for several days; they are of a dark grey colour and measure up to $0.090 \mathrm{~mm}$. in length, being rather longer than broad; those fed on diatoms for a week measured $0.093 \mathrm{~mm}$. in length (Grave). Nelson (I923) estimates the free-swimming life of a 'viviparous' Teredo (species not given) as from 3 to 4 weeks, the larvae increasing over one hundred times their original bulk. In I924, he states that examples of Teredo, three-fifths of an inch in length, have been found to be breeding in less than 3 weeks from the 
time that they attached themselves to the wood. When full grown they were $8 \mathrm{in}$. long. These last were from Barnegat Bay, New Jersey. Grave (I928) found that larvae of $T$. navalis were present in the sea at Woods Hole, Massachusetts, from early May to October and he estimated that in summer they matured in 6-8 weeks. The typical $T$. navalis as recognized by Kofoid, Grave and Miller from San Francisco, and as described by European workers, may breed at a length of 4 in., but usually the adult is from 6 to 8 in. in length, reaching in extreme' cases to over a foot.

Teredo navalis var. from Plymouth (Figs. I-3). The pallets have no cup-like depression of the calcareous blade, but the end is rounded and the dark periostracal sheath reaches to about one-quarter the length of the blade and is very dense, extending beyond the blade for a distance, sometimes as long as the blade itself, the distal portion being pale brown and either straight or forked. In some cases a calcareous deposit, hardly amounting to a nodule, occurs in this distal periostracal portion. The siphons are nearly equal and are perfectly colourless, the exhalant siphon ending simply, the inhalant with six tentacles with knobs in between. The shell is like $T$. navalis, the central portion being rather longer. It may breed at a length of less than an inch and is rarely more than 2 in. long. The body is stout and short; the brood sac contains veligers in every month of the year, some of them always in the free-swimming stage and ready to be extruded; the late veligers appear brownish owing to the edges being dark brown. These are briefly described in an earlier paper (Lebour, 1938). Since then they have been studied in more detail and reared after entering the wood until the beginning of the tube is formed. The latest veligers which are ready to emerge and are sometimes seen issuing from the exhalant siphon measure $0.32 \mathrm{~mm}$. in length and are thus distinctly larger than those of $T$. navalis of the American workers. When the parent is removed from the tube there are generally some veligers emerging, and frequently the egg sac bursts and the veligers are freed. The veligers swim freely, and if placed in a bowl of water rise to the surface, swimming actively. If wood is near they usually swim to it and move about on it, creeping by the long retractile foot, feeling their way. If placed in a bowl of water or plunger jar with small pieces of wood, within $24 \mathrm{hr}$. they may be resting on these and sometimes, with difficulty, a small byssus thread at the base of the foot may be seen. Within $36 \mathrm{hr}$. the veliger may have begun to metamorphose. Mr D. P. Wilson has been making experiments on the settling of these larvae, the results of which he will publish later. After extrusion from the parent a pair of semicircular orange patches appear near the margin under the shell (the eyes ?) which remain until burrowing begins. The velum is lost and the siphons are formed, whilst round the anterior margin a toothed ridge, followed quickly by a second, is formed. The ventral margin curves in where the knobs are forming and the blades appear. The foot is ciliated, long, and very flexible, but it soon dwindles when the animal settles down in the wood, anterior 
margin downwards, siphons upwards. The toothed ridges are the burrowing organs and burrowing begins now the animal has settled down. In about four days or even less, a white cloudy mass may cover the shell, apparently the beginning of the limy tube, and a few days after there is a white chalky raised

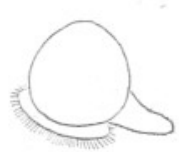

$a$
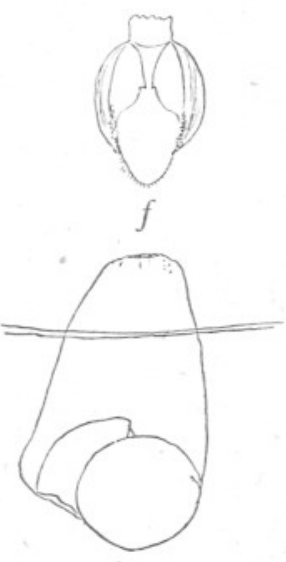

$k$

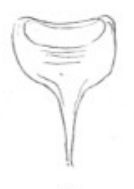

0

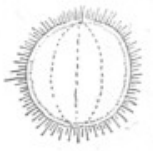

$b$

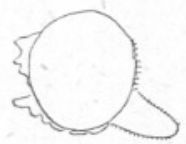

C

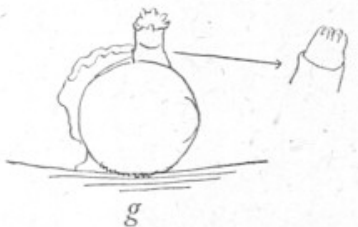

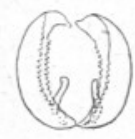

$d$

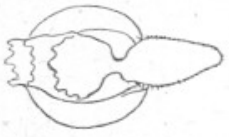

e
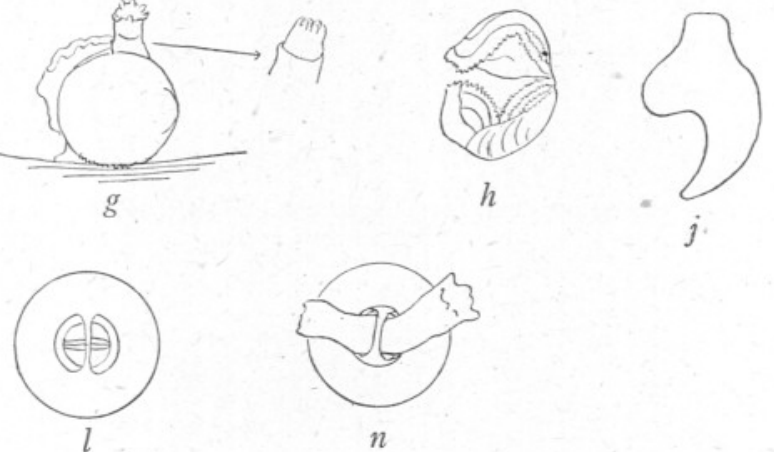

$n$
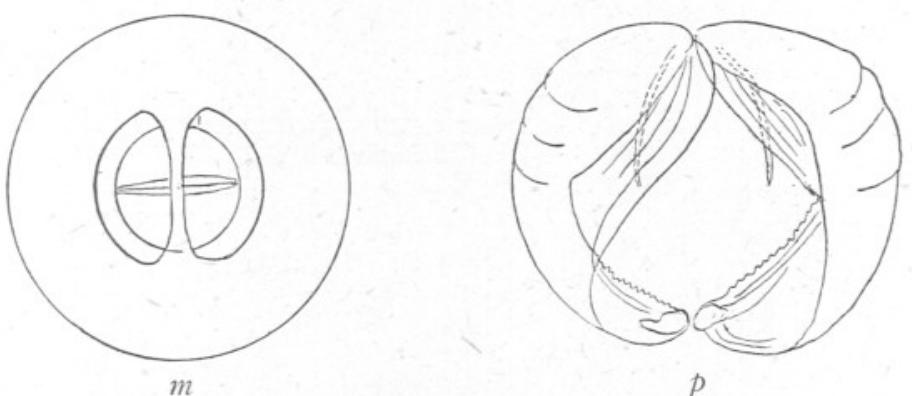

$p$

Fig. I. Teredo navalis var. from Plymouth raft. $a, b$, veliger just emerged from parent, $0.32 \mathrm{~mm}$. long; $c$, the same beginning to metamorphose; $d$, slightly older shell; $e$, seen from ventral aspect; $f$, shell $0.36 \mathrm{~mm}$. long; $g$, larva settling on wood, $0.36 \mathrm{~mm}$. long; $h$, older shell from wood, $0.40 \mathrm{~mm}$. long and across; $j$, tube of shell $0.6 \mathrm{~mm}$. long; $k$, slightly older animal showing portion of tube above and below the wood; $l$, top of tube of same looking down, showing double aperture with septum and pallets; $m$, the same enlarged; $n$, the same showing siphons extended; $o$, pallet, $0.16 \mathrm{~mm}$. long, of animal with shell $0.6 \mathrm{~mm}$. across; $p$, shell $0.6 \mathrm{~mm}$. across.

covering, looking not unlike a very young sessile barnacle, rising up from the wood with an aperture divided into two by a partition. From the holes the siphons may hang out conspicuously. When the siphons are retracted the closed pallets can be seen within at right angles to the partition. The shell dissected out has the rudiments of the adult structure at about $0.4 \mathrm{~mm}$. and there are 
more toothed ridges which now extend on to the ventral margin. In a young animal with the shell $0.6 \mathrm{~mm}$. across, the pallets are well formed and measure $0.16 \mathrm{~mm}$. in length with the stalk about the same length as the blade, the latter being broader than long and hollowed distally. It is brown, but has not yet a
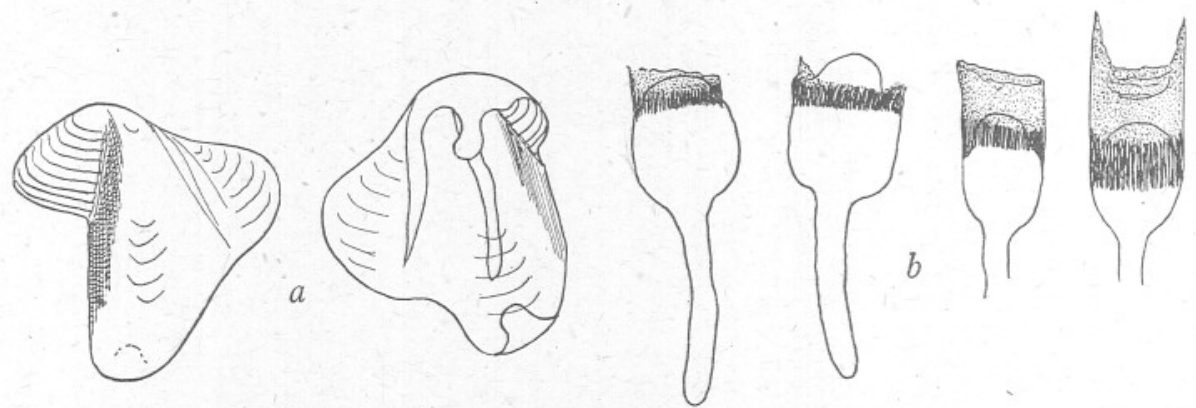

Fig. 2. Teredo navalis var. from Plymouth. $a$, shell of adult animal, $\mathrm{I} \cdot 8 \mathrm{mri} ;$ long; $b$, pallets of various adults, c. $2 \mathrm{~mm}$. long.

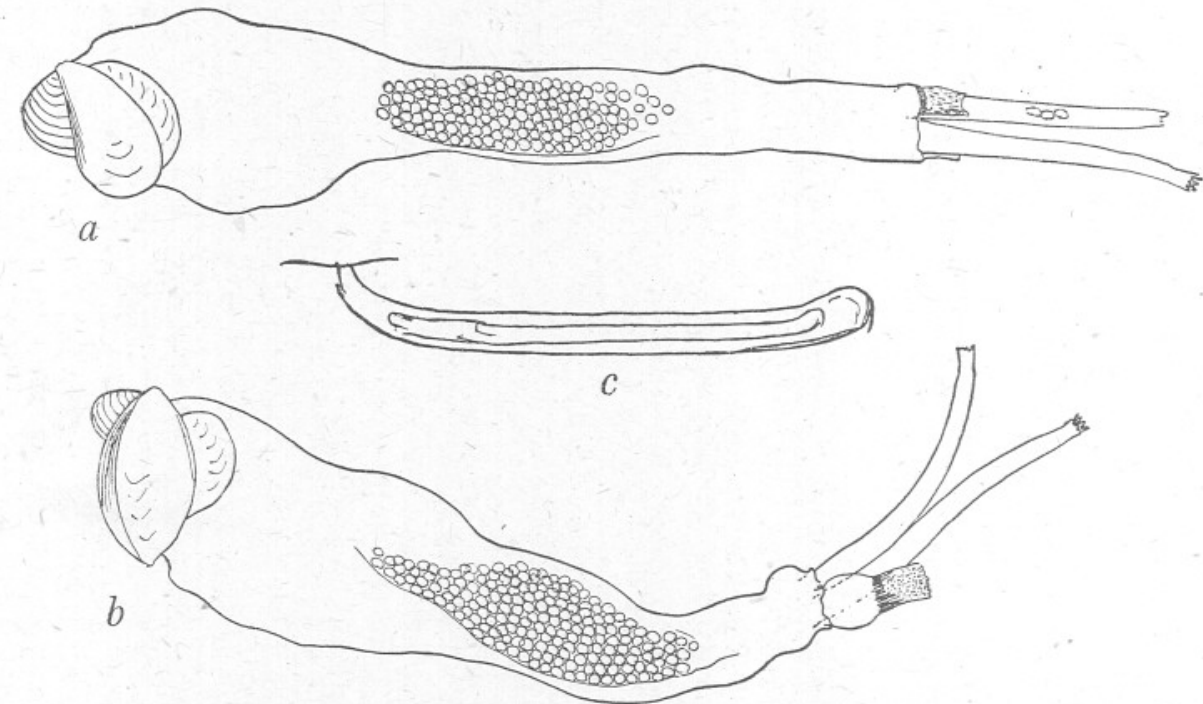

Fig. 3. Teredo navalis var. from Plymouth. Rough sketches of adult animals. $a, b$, dissected out of tube and $c .2 \cdot 2 \mathrm{~cm}$. and $2 \cdot 0 \mathrm{~cm}$. long respectively; $c$, typical adult in tube, natural size, $5.5 \mathrm{~cm}$. long.

brown sheath projecting from its end. This young pallet is interesting as it is at this stage much more like that of the typical $T$. navalis. The tube now protrudes from the wood as a conical prominence, the tube itself inside the wood being rather longer than the shell itself and tightly attached to it. As the animal grows the division in the aperture of the tube disappears and there is only one hole, the limy top being hidden in the wood and the presence of the 
Teredo only showing by a very small perforation, the siphons emerging when conditions are favourable.

Free-swimming veligers of this species have only rarely been seen in the plankton and these were isolated specimens. It is probable that any period of swimming in the sea is very short. The breeding season continuing throughout the year makes infection of the wood possible at any time, but the short period of free moving probably prevents long journeys in the water. On the other hand, they live for a long time in the wood which if broken off may be drifted far. The wood may be extensively infected but not very deeply, not so deeply as with $T$. norvegica, which nearly always occurs with it. The isopod Limnoria and the amphipod Chelura are nearly always associated with these two Teredo species in the raft.

Although the wood may be extensively infected it is probable that this small form would not do so much damage as the typical $T$. navalis nor as $T$. norvegica, but the fact that there is no cessation in breeding is an important point, as there would be no period when infection could not be carried out. This is contrary to the idea that in Holland few individuals survive the winter (Calman \& Crawford, I936, p. I4). The question whether the typical $T$. navalis and this small one are different species is left for future workers to decide. The nearest species so far described is $T$. diegensis Bartsch, but it also comes near $T$. townsendi Bartsch. These three small forms stand together in contrast to the typical $T$. navalis.

Teredo megotara Forbes \& Hanley. This species is occasionally found in driftwood from the Plymouth district. On I September I943 a large piece of a heavy wooden case which had drifted into Wembury Bay was brought to the laboratory by Mr F. G. C. Ryder. It was riddled with T. megotara and small specimens of Lepas (anatifera?) were hanging from it. The Teredo were of all sizes, the largest being females containing ova, but these were not quite mature. Pieces of the wood were taken to the raft by the Breakwater and fixed to it in order to see if ripe ova could be obtained. Examined a month later the ova were still immature. In January I944 a curious formation of lime was seen round the mouths of the tubes, having the appearance of the tubes of Serpula. This closely resembled the calcareous tubes covering the siphons of Teredo norvegica in the Plymouth tank described by Yonge (I927) formed round faecal deposits. In $T$. megotara, however, the calcareous tubes were exposed in the water. It may well have been a response to uncongenial conditions when the life on free drifting wood ceased. The ova and sperm contained in different individuals were ripe at this time, or the animals were spent. The ova were running out of some of the females, which were much larger than the males. Fertilizations were attempted, but the eggs and sperm were not healthy and only a few fertilized ova were obtained which grew to a stage in which the embryo was active but soon died. It seems that the young are not held in a brood pouch but that the ova are shed directly into the sea. 
Xylophaga dorsalis Turton. Pieces of wood bored by Xylophaga were brought in from a trawler by $\mathrm{Mr} \mathrm{A}$. Briggs. One of these was part of a branch dredged 5 or 6 miles south of Penlee (29 March 1943) which was riddled by Xylophaga. Nearly all contained ripe ova, some of which were extruded on touching with a needle. Any sperm present was non-motile and fertilizations were unsuccessful. There was no trace of live embryos, and the large clouds of ova coming from each individual when opened seem to be a clear indication that this species does not carry its young in a brood pouch, but is more like $T$. norvegica than $T$. navalis, sending its ova directly into the sea.

Pieces of driftwood were brought in from trawling 3 miles south of Rame (4 November 1943). One small piece contained both $T$. norvegica and Xylophaga. The Teredo contained ripe ova and sperm. The pieces were probably broken off from some fixed wood, and the Xylophaga may have entered afterwards. The other pieces all contained Xylophaga only, with ripe eggs and sperm, clouds of which issued when the animal was injured. There was no sign of contained embryos. Fertilizations were attempted and one was partially successful, the embryos living for a few days only. The ripe ovum measured c. $0.027 \mathrm{~mm}$. across; the size scarcely altering after fertilization (the ova of T. norvegica measure $c .0 .05 \mathrm{~mm}$. across). It is shown by Purchon (I94I) that self-fertilization is possible, but it seems from these observations that the embryos are not carried in a brood pouch. On one occasion specimens obtained from a piece of a branch of wood (2-3 miles south-east of Eddystone, II November 1943) were full of ripe ova, and in one it was seen that some of the loose ova were developing, showing almost certainly that self-fertilization had taken place, but there was no sign of embryos in the gills. Ripe ova also occurred in specimens from wood brought in from trawling outside the Sound (2 December 1943). The breeding season of Xylophaga thus extends at least from November to March.

\section{REFERENCES}

BARTSCH, P., 1922. A monograph of the American shipworms. Smithsonian Institution. U.S. Nat. Mus. Bull., No. I22, pp. I-50.

CALMAN, W. T. \& CRAWFORD, G. I., I936. Marine boring animals injurious to submerged structures. British Museum (Natural History) Economic Series, No. Io, pp. $\mathrm{I}-38$.

Forbes, E. \& Hanley, S., I853. A History of British Mollusca, Vol. I, pp. I-486; Vol. IV, plates.

Grave, B. H., I928. Natural history of shipworm, Teredo navalis, at Woods Hole, Massachusetts. Biol. Bull., Vol. Lv, pp. 260-82.

HARINGTON, C. R., I922. Report of work done at the Marine Biological Station, Plymouth, July Ist to Sept. I8th, I920. Deterioration of structure of timber, metal and concrete exposed to action of sea-water. Second (Interim) Report on the Committee of the Institution of Civil Engineers, pp. 35-42.

Jefrereys, J. G., I865. British Conchology, Vol. III, pp. I-393; Vol. v, plates.

Kofold, C. A., I921. Report on the San Francisco Bay Marine Borers, pp. 23-6r.

- 1922. The San Francisco Bay Marine Piling Survey. Second Annual Progress Report, Biological Section, pp. 72-8r. 
LAZIER, E. L., I924. Morphology of the digestive tract of Teredo navalis. Univ. Calif. Publ. in Zool., Vol. xxII, No. I4, pp. 455-77.

Lebour, M. V., I938. Notes on the breeding of some Lamellibranchs from Plymouth and their larvae. Fourn. Mar. Biol. Assoc., Vol. xxiII, pp. II9-44.

MilleR, R. C., I922. Variations in the shell of Teredo navalis in San Francisco Bay. Univ. Calif. Publ. in Zool., Vol. xxII, No, 2, pp. 294-320.

Nelson, Thurlow C., I923. The European pileworm. A dangerous marine borer in Barnegat Bay, New Jersey. Circular 139, New fersey Agricultural Experimental Station, pp. I-I5.

- 1924. Report of the Department of Biology of the New Fersey Agricultural College Experimental Station, New Brunswick, N.F., for the year ending fune $30 t h$, 1923.

Orton, J. H., I913. Preliminary account of a contribution to an evaluation of the sea. fourn. Mar. Biol. Assoc., Vol. x, pp. 312-26,

Purchon, R. Denison, I94I. On the biology and relationships of the Lamellibranch Xylophaga dorsalis (Turton). Fourn. Mar. Biol. Assoc., Vol. xxv, pp. I-89.

Yonge, C. M., I926. Protandry in Teredo norvegica. Quart. Fourn. Micro. Sci., Vol. Lxx, pp. 39I-4.

1927. Formation of calcareous tubes round the siphons of Teredo. Nature, pp. II-I2. 